\author{
Piotr Uczkiewicz \\ Zespół Szkół Ogólnokształcących, Bochnia
}

\title{
Technologia informacyjna a przedsiębiorczość w szkole ponadgimnazjalnej
}

\section{WSTĘP}

Rozwój społeczeństwa informacyjnego, rozwój cywilizacji naukowej i technicznej oraz globalizacja gospodarki - to trzy podstawowe czynniki zmian, mające wpływ na rozwój przedsiębiorstw i na system edukacji. Wszystkie wymienione czynniki przekładają się na zadania dla edukacji. Próbą odpowiedzi na nowe zmiany (równocześnie nowe wyzwania) jest przebudowa koncepcji edukacyjnych, która dokonuje się w polskim systemie edukacji.

Zreformowana edukacja, odpowiadająca gospodarczym i społecznym trendom, musi większym stopniu koncentrować się na przekazywaniu umiejętności samodzielnego działania i kształtować zdolności do szybkiej samoorganizacji i przedsiębiorczej adaptacji do zmieniających się warunków oraz sposobów działania. W nowych warunkach zdynamizowanej i wysoce konkurencyjnej gospodarki otwartej, o zasięgu globalnym, kluczowymi wyznacznikami bogactwa i zdolności konkurencji stają się aktywność, innowacyjność, przedsiębiorczość, komunikacyjność, które to razem stwarzają możliwość podjęcia inicjatywy gospodarczej (Okoń-Horodyńska,1999).

We wrześniu 2002 roku szkoły ponadgimnazjalne zostały objęte reformą systemu edukacji narodowej. Wprowadzono nowy przedmiot podstawy przedsiębiorczości oraz zastąpiono elementy informatyki dwoma przedmiotami informatycznymi: technologią informacyjną i informatyką. Pragnę przekonać nieprzekonanych, że we współczesnym świecie połączenie wiedzy informatycznej z ekonomiczną jest niezbędne i powinno być realizowane w postaci zajęć z przedsiębiorczości w szkole ponadgimnazjalnej.

\section{REFLEKSJE}

Konferencja ${ }^{1}$ stworzyła doskonałą okazję do refleksji nad miejscem edukacji we współczesnym świecie i wyzwaniami, jakie stanęły przed edukacją. Jako nauczyciel - świadek przemian, chciałbym przedstawić kilka wybranych przykładów:

\section{Dbalość uczelni/szkoły o swój wizerunek}

Przełamany po roku 1990 monopol państwa w zakresie kształcenia na poziomie wyższym zaowocował burzliwym rozwojem szkolnictwa wyższego, głównie niepublicznego. Zaczęły również powstawać i rozwijać się szkoły policealne, szkolnictwo średnie i podsta-

\footnotetext{
${ }^{1}$ Autor nawiązuje do obrad Pierwszej Ogólnopolskiej Metodycznej Konferencji Naukowej „Przedsiębiorczość a współczesne wyzwania cywilizacyjne”, która odbyła się w Krakowie, dn. 27-28 września 2004 r. (organizator: Zakład Przedsiębiorczości i Gospodarki Przestrzennej Instytutu Geografii Akademii Pedagogicznej w Krakowie oraz Krajowe Centrum Edukacji Nauczycieli) - przyp. red.
} 
wowe (prywatne, społeczne). Uczelnie/szkoły zaczęły ze sobą konkurować. Strategia konkurencyjności głosi: „, oferta wartości to nie wszystko, musisz także poradzić sobie z rynkowymi rywalami!"

Nowe placówki, chcąc znaleźć sobie miejsce wśród już istniejących, musiały zdobyć zainteresowanie i zaufanie studenta/ucznia. Dla nich także ważna stała się opinia otoczenia, od której zależy przyszłość i rozwój placówki. Autorzy książki „,Upadek reklamy i wzlot Public Relations" Al i Laura Ries przekonują, że nie da się wprowadzić na rynek nowej marki za pomocą reklamy, bo jest ona tylko głosem firmy troszczącej się o swoją sprzedaż, a zatem mało wiarygodną. Nową markę można wprowadzić wyłącznie dzięki public relations (PR). Rola reklamy sprowadza się do podtrzymania i wzmocnienia w umysłach odbiorców wyobrażeń o marce, wykreowanych przez PR. Działania z obszaru PR zostały przejęte do szkół z firm komercyjnych. Różnica między firmą a szkołą jest taka, że w firmie zajmuje się tym oddzielny wydział (lub firma zewnętrzna) a w przypadku szkoły najczęściej jest nim sam dyrektor szkoły lub osoba przez niego wyznaczona albo grupa nauczycieli tworząca zespół ds. promocji szkoły. Kto jest pracodawcą szkoły? Zawsze jest nim klient. W tym wypadku klientem będzie student lub uczeń i dlatego należy walczyć o przyszłego ucznia/studenta.

„Odkryj, czego pragnie klient, nawet jeśli on sam tego jeszcze nie wie” - tak brzmi cytat z księgi zasad Procter \& Gamble. Uczelnia/szkoła w reklamie najczęściej przedstawiana jest jako nowoczesna placówka, która wykorzystuje najnowsze technologie np. chip karty, bezprzewodowy dostęp do Internetu.

\section{Edukacja w warunkach globalizacji}

Globalizacja istnieje także w edukacji i ma charakter obiektywny. Można ją popierać lub jej się przeciwstawić, ale nie wolno jej ignorować.

Tab. 1. Szanse i zagrożenia edukacji w warunkach globalizacji.

\begin{tabular}{|c|c|c|}
\hline & & \\
\hline & $\begin{array}{l}\text { Oparcie rozwoju ekonomicznego i społecznego na wiedzy } \\
\text { i kapitale intelektualnym, } \\
\text { Jakość edukacji staje się tematem politycznym i eko- } \\
\text { nomicznym, } \\
\text { Rozwój technologiczny przyspiesza przemiany w edukacji, } \\
\text { Wzrasta rola kształcenia ustawicznego, uczenie się przez } \\
\text { całe życie, } \\
\text { Następuje popularyzacja wykształcenia, pęd do wiedzy, } \\
\text { Wzmacniają się tendencje do standaryzacji nie tylko na } \\
\text { poziomie krajowym, ale także międzynarodowym np. nowe } \\
\text { standardy językowe dla na-li - B2, B2+, } \\
\text { Wejście Polski do UE zwiększa dodatkowo przepływ kapi- } \\
\text { tału, transfer wiedzy i informacji oraz dostęp do technologii } \\
\text { i know-how. }\end{array}$ & $\begin{array}{l}\text { Edukacja jest in- } \\
\text { strumentem i zara- } \\
\text { zem polem uprawia- } \\
\text { nia polityki, } \\
\text { Biznes chce kształ- } \\
\text { tować i kształtuje } \\
\text { edukacje, } \\
\text { Kształcenie staje się } \\
\text { drogie, więc istnieje } \\
\text { wyraźne ryzyko po- } \\
\text { działu na bogatych } \\
\text { i mądrych oraz bied- } \\
\text { nych i niedouczo- } \\
\text { nych. }\end{array}$ \\
\hline
\end{tabular}

Źródło: Krzysztof Głuc IRE WSB-NLU w Nowym Sączu - materiały konferencyjne z Ogólnopolskiej Konferencji dla Dyrektorów Szkół Średnich „Jakość w edukacji -wyzwanie XXI wieku”, Krynica,10 -13 IV 2003 r. (zmienione).

\section{Korporacje IT w uczelni / szkole}

Prawie wszystkie największe polskie uczelnie nawiązały już współprace z firmami komercyjnymi w zakresie IT. Dla szkół współpraca $\mathrm{z}$ firmami komercyjnymi w ramach inicjatyw akademickich stała się szansą na poprawienie notowań w rankingach i uzyskanie 
większej popularności. Taka forma współpracy umożliwia szybką aktualizację wiedzy studentów bez całego bagażu formalnego, koniecznego przy dokonywaniu zmian w programach nauki. Dużym zainteresowaniem wśród studentów cieszą się kursy w ramach 170 Akademii Sieciowych Cisco. Kilka tysięcy studentów uczy się technologii Microsoftu, Novella i Sun Microsystems. Ponad 100 szkół ponadgimnazjalnych i policealnych posiada Lokalne Akademie Cisco. Za udział w programach firm komercyjnych trzeba płacić, jednak mniej niż w firmach szkoleniowych. Korporacje również są autorami szkoleń dla nauczycieli. Firma Intel uruchomiła program „Intel - nauczanie ku przyszłości, a firma Microsoft rusza z inicjatywą „Partnerstwo dla przyszłości”. Intel nie jest pierwszą firmą o zasięgu globalnym inwestującą w edukację. Koncerny branży IT poprzez różne systemy edukacyjne i rabatowe próbują przyciągnąc szkolnictwo różnych państw do swoich produktów. „Taka forma marketingu (finansowanie kształcenia) pozwala tym firmom na edukowanie nie tylko nauczycieli, ale również przyszłych klientów - uczniów, którzy po skończeniu szkoły wejściu w dorosłe życie sięgna zapewnie w pierwszej kolejności po „marki”, które poznali w szkole” (Stefanowski, 2001).

\section{Absolwent na rynku}

W 1967 roku Wall Street Journal przedstawił przepowiednie na rok 2000: człowiek na Marsie, miasta pod ogromnymi klimatyzowanymi kloszami, podróż z Tokio do Nowego Yorku mniej niż w 2 godziny, latające samochody, 200 tys. komputerów w USA.

Z perspektywy 2004 roku przewidywania są bardzo dziwaczne, może oprócz ilości komputerów (duża pomyłka). Ponieważ istnieje przełożenie pomiędzy rewolucją ekonomiczno - informatyczną (która trwa i przyspiesza) a reformami edukacji należy stwierdzić, że jej skutki są trudne do przewidzenia.

Trudno jest określić, jaki będzie rynek pracy np. w 2010 roku. Szkoły i uczelnie stoją przed zadaniami: z jednej strony istnieje jeszcze problem nieprzystosowania kwalifikacji uzyskiwanych w systemie edukacyjnym, w stosunku do wymagań obecnego rynku pracy, a z drugiej strony istnieje problem trafnej przewidywalności sytuacji rynku pracy dla absolwentów za kilka lat.

Także samo pojęcie pracy ulega ewolucji. Światowe rynki pracy, podążając za Ameryką i Japonią, wchodzą w erę pracowników tymczasowych, konsultantów i podwykonawców. W miejsce stałych etatów wkracza siła robocza zatrudniana na określony czas i do wykonania określonego zadania lub projektu.

\section{TECHNOLOGIA INFORMACYJNA W NAUCZANIU PRZEDSIĘBIORCZOŚCI W SZKOLE PONADGIMNAZJALNEJ}

Przeglądając charakterystykę programu nauczania podstaw przedsiębiorczości z zainteresowaniem przeczytałem rozdział: stosowanie technologii informacyjnej $w$ realizacji programu podstaw przedsiębiorczości. ${ }^{2}$

„Podstawy przewiduja między innymi kształtowanie umiejętności porozumienia się w różnych sytuacjach. W dobie umacniania się spoleczeństwa informacyjnego oraz kultury medialnej najszybciej rozwijajaca się forma komunikacji międzyludzkiej staje sie Internet, zwłaszcza, że jest on dostępny przez łacza telekomunikacyjne, w tym również telefonię komórkowa. Dlatego zadanie to można realizować, wykorzystujac w procesie dydaktyczno wychowawczym nowoczesne technologie informacyjne. Na potrzebe ich stosowania jednoznacznie wskazuje podstawa programowa, a ściśle punkt 5. dotyczacy nabywania przez uczniów umiejętności poszukiwania, porzadkowania i wykorzystywania informacji z różnych źródet oraz efektywnego postugiwania się komputerami i metodami informatyki. Kolejny

\footnotetext{
${ }^{2}$ Program nauczania „Podstawy przedsiębiorczości”, Operon, Gdynia 2003.
} 
punkt podstawy (6.) zakłada kształtowanie umiejętności odnoszenia się do praktyki zdobytej wiedzy oraz tworzenie potrzebnych doświadczeń i nawyków. "

Program przewiduje wykorzystywanie encyklopedii multimedialnych i internetowych, stron związanych z przyszłą karierą zawodową, rynkiem pracy, instytucji związanych z gospodarką kraju. Można wykorzystać dostępne w sieci gry i symulacje, między innymi symulacje inwestowania na Giełdzie Papierów Wartościowych w Warszawie.

Aby tak się stało, muszą zostać rozwiązane dwa problemy. Pierwszy to umiejętności komputerowe nauczycieli. Drugi problem dotyczy wykorzystania pracowni komputerowej do zajęć lekcyjnych z przedsiębiorczości.

Korzystanie z komputera, Internetu to nie tylko przymus technologiczny, lekcje wspomagane nowymi technikami stają się bardziej atrakcyjne dzięki wykorzystaniu CD, Internetu, symulacji, wizualizacji. $\mathrm{W}$ związku $\mathrm{z}$ awansem zawodowym zostało przeszkolonych tysiące nauczycieli z zakresu stosowania IT. Awans zawodowy zakłada, że każdy nauczyciel jest nauczycielem technologii informacyjnej w zakresie swojego przedmiotu, którego uczy. $Z$ własnych doświadczeń mogę stwierdzić, że wśród pewnej grupy nauczycieli jeszcze istnieją pewne opory przed pracą z komputerem. Część nauczycieli jest przekonana, że można dalej uczyć bez znajomości technologii komputerowych.

Gdy została wydrukowana pierwsza książka, wywołało to wielkie poruszenie na Sorbonie. Profesorowie uważali, że stracą pracę, jeżeli każdy student będzie miał książki to nie będzie potrzebował nauczyciela. Doszło do tego, że kadra profesorska złożyła petycję do króla, aby zabronił importu książek do Francji. Książki zostały wprowadzone, profesorowie zatrzymali swoje posady i nadal będą potrzebni.

Obawa, że systemy on-line wyprą profesorów z większości instytucji dydaktycznych i zastąpią ich zautomatyzowanymi modułami on-line nie wydaje się być uzasadniona, ponieważ badania dotyczące oczekiwań studentów potwierdzają, że personalna opieka naukowa jest jedna głównych cech, jakie studenci on-line wysoko sobie cenią (Bołtuć, 2001).

Pod wpływem technologii informacyjnych zmienia się rola nauczyciela / profesora w wieku informacji. Nauczyciel i klasy szkolne nie są podstawowym źródłem informacji. Nauczyciel musi być przewodnikiem ucznia w zdobywaniu informacji istotnych dla danej dziedziny wiedzy. Nauczyciel musi nauczyć ucznia, jak informacje należy oceniać. Nauczyciel ułatwia zdobywanie wiedzy, staje się przewodnikiem. My nauczyciele jesteśmy również „uczniami” i musimy się ciągle uczyć w szybko zmieniającym się świecie. Ciągle będziemy stać przed wyzwaniem przełamania oporów przed nowymi rozwiązaniami technologicznymi. To jest nasz wybór: możemy kontynuować model XIV wiecznego uniwersytetu, tak jak to czynimy, odkąd wynaleziono druk lub możemy wykorzystywać nowe technologie i być częścią elektronicznego uniwersytetu na miarę XXI wieku ${ }^{3}$.

$\mathrm{Z}$ dniem 1 października $2004 \mathrm{r}$. wchodzi w życie rozporządzenie Ministra Edukacji Narodowej i Sportu dotyczące standardów kształcenia nauczycieli na studiach wyższych zawodowych, uzupełniających studiach magisterskich, jednolitych studiach magisterskich oraz studiach podyplomowych. W załączniku do rozporządzenia mowa jest o kształceniu w zakresie technologii informacyjnej. Przygotowanie do zawodu nauczyciela powinno prowadzić do nabycia kompetencji w zakresie: informacyjno-medialnym - wyrażającym się umiejętnością posługiwania się technologią informacyjną, w tym jej wykorzystywanie $\mathrm{w}$ nauczaniu przedmiotu (prowadzenie zajęć).

Rozporządzenie szeroko określa, jaką wiedzę i umiejętności powinno obejmować przygotowanie do zawodu nauczyciela (cztery zakresy) ${ }^{4}$.

Drugi problem to swobodny dostęp do pracowni komputerowej nauczyciela przedsiębiorczości. W pracowni komputerowej mogą odbywać w tym samym czasie lekcje z technologii informacyjnej lub informatyki oraz nie każdy opiekun pracowni wyraża aprobatę na

\footnotetext{
${ }^{3}$ Bob Spear, Wideokonferencja, 2001, PAM Center Łodź.

${ }^{4}$ szczegóły na stronie www.menis.gov.pl
} 
„wypożyczenie” pracowni. Najlepszym rozwiązaniem są dwie pracownie w szkole, jedna dla przedmiotów informatycznych, a druga do wykorzystania przez nauczycieli z innych przedmiotów.

Jeżeli zostaną spełnione warunki dotyczące umiejętności komputerowych nauczycieli, oraz zostanie zapewniony swobodny dostęp do pracowni należy zadać pytanie o wybór zakresu treści dla przedmiotu podstawy przedsiębiorczości, które powinny być realizowane przy zastosowaniu technologii komputerowych.

Moim zdaniem, w nauczaniu przedsiębiorczości brakuje modułu dotyczącego e-biznesu. E-Biznes to biznes elektroniczny, to sposób prowadzenia firmy, polegający na wykorzystaniu technik informacyjnych (IT), w którym szczególnie ważne jest dostarczenie klientowi produktu o najlepszej jakości.

Zalety e-biznesu stały się źródłem fundamentalnych zmian w sposobie organizacji i prowadzenia firmy. Świat biznesu wciąż rozwija się dzięki technologiom informacyjnym. Każda firma, aby być konkurencyjną powinna przeanalizować wpływ wprowadzenia strategii e- biznesu. Każda strategia powinna obejmować tworzenie nowych rynków i zdobywanie nowych klientów. Rozwój technik informacyjnych umożliwił szybkie zdobywanie klientów na całym świecie. Najbardziej efektowne są te przedsięwzięcia, które umiejętnie łącza „fizyczny" biznes z możliwościami, które daje sieć. Usługi WWW są obecnie najpopularniejszym sposobem pozyskiwania informacji biznesowych oraz najtańszym sposobem marketingu i promocji produktów i usług, a także nawiązywania bezpośrednich kontaktów z kontrahentami.

E-biznes jest elementem nowej gospodarki (ekonomii), której początki zostały dostrzeżone w 1968 r., kiedy Peter Drucker dostrzegł nadejście pracowników wiedzy (knowledge workers). Nowa gospodarka często jest nazywana gospodarką opartą na informacji, poprzez zwiększanie jej roli wobec innych zasobów produkcji (kapitału i zasobów materialnych) w tworzeniu bogactwa. W dobie Internetu powstała następna definicja według której nowa gospodarka to wpływ technologii informacyjnych i telekomunikacyjnych (ICT), lub bardziej szczegółowo - Internetu - w tworzeniu przyspieszonego wzrostu produktywności ${ }^{5}$.

Infrastruktura techniczna e-biznesu napotyka niekiedy na bariery np. dostępności i kosztu połączeń, przepustowości linii, obsługi płatności on-line, certyfikacji uczestników transakcji. Firmy oraz osoby prywatne wykorzystujące Internet jako medium muszą mieć jasność co do swoich praw i obowiązków, a także potencjalnych zagrożeń i zabezpieczeń prawnych (Henschke, 2000).

$\mathrm{Na}$ lekcjach $\mathrm{z}$ technologii informacyjnej omawia się zagadnienia dotyczące rozwoju społeczeństwa informacyjnego. Podaje się definicje e-biznesu, podobnie jak e-edukacji, e-pracy, e-urzedu. Szersze potraktowanie e-biznesu powinno mieć miejsce na lekcjach przedsiębiorczości.

Istnieje wiele firm działających jako wirtualne. Każde przedsiębiorstwo w mniejszym lub większym stopniu wdraża systemy informatyczne, na których opiera się e-biznes. Systemy ERP to zintegrowane systemy zarządzania, które gromadzą informację w firmie i zajmują się jej obiegiem. Systemy CRM, czyli systemy zarządzania relacji z klientami, hurtownie danych, systemy obiegu dokumentów w firmie (EDI), programy do pracy grupowej to tylko niektóre nowoczesne narzędzia we współczesnej firmie.

\section{PODSUMOWANIE}

Uważam, że osoba przedsiębiorcza, kreatywna, pragnąca założyć własną firmę powinna poznać moduł z e-biznesu na lekcjach z przedsiębiorczości. Moim zdaniem wystarczą

\footnotetext{
${ }^{5}$ www.kneb.org/ekonomia.php
} 
cztery lekcje w pracowni komputerowej. Pracownia komputerowa jest najbardziej odpowiednim miejscem (i jedynym) do realizacji tego modułu.

Nauczyciel powinien dysponować płytą CD zawierającą gotowe symulacje działania programów i systemów e-biznesowych podparte opinią osób wdrażających te systemy. W żadnym razie nie wymagam od nauczycieli przedsiębiorczości umiejętnością pracy z tymi programami/systemami, których używanie nawet przez doświadczonych informatyków bez specjalnych kursów i certyfikatów jest niemożliwe ze względu na wysoki stopień ich trudności.

W podsumowaniu stawiam następujące wnioski:

1. Należy wprowadzić do programu nauczania przedsiębiorczości moduł dotyczący e-biznesu - autorzy programów.

2. Wyposażyć nauczycieli w wiedzę i umiejętności na ten temat poprzez stosowne szkolenie (wystarczy jednodniowe, bezpłatne) - firmy szkoleniowe IT działające przy uczelniach.

3. Zaopatrzyć szkoły $\mathrm{w}$ bezpłatne pomoce dydaktyczne $(\mathrm{CD}$ z symulacjami systemów informatycznych - powinny być tym zainteresowane firmy produkujące oprogramowanie biznesowe).

4. Stworzyć na te potrzeby przez ww. firmy portalu edukacyjnego dla nauczycieli przedsiębiorczości.

5. Nauczyciele powinni mieć swobodny dostęp do pracowni komputerowej z możliwością podziału na grupy - szkoła.

6. Nauczyciele powinni mieć większe uznanie za swój wkład w pracy z uczniami - dyrekcja, organy prowadzące.

\section{LITERATURA}

Bołtuć P., 2001, Edukacja bez dystansu, Mentor nr 1, SGH Warszawa.

Henschke P., 2000, Sześć kroków do sukcesu, Businessman nr 5, Warszawa.

Okoń-Horodyńska E., 1999, Nauczanie na odległość-nowa szansa dla edukacji, Śląskie Wydawnictwo Naukowe, Tychy.

Stefanowski R., 2001, Program ksztatcenia nauczycieli $w$ dziedzinie informatyki „Intel Nauczanie ku Przyszłości”, Edukacja medialna nr 4, Poznań. 